\title{
Collective Learning and Socialization During the Ecological Transition: the case of organic and biodynamic wine producers of Côte de Beaune
}

Jaime Montes-Lihn'

\section{Abstract}

Wine producers facing the transition to organic farming rely widely on networks of informal advice sharing among peers. Limited attention has been paid so far to the impact of actors' values on collective learning, although the literature shows that they play a role both in the ecological transition (LAMINE et al., 2009) and in advice seeking (NAHAPIET et al., 1998). This paper explores the effect of actors' ecological values on a complete advice network within a professional milieu of over 60 organic and biodynamic wine producers in Burgundy Region, France. Using exponential random graph models, the analysis takes into account not only wine producers' ecological values, but also their broad relational context including triadic sub-structures such as transitivity and the existence of pre-existing relations that may have an influence on the advice network. Wine producers' values stand out as driving the selection of advisers. Two simultaneous collective learning processes are identified: the first one is characterized by the collaboration of experienced wine producers that share common ecological values, and the second one by the interactions among these experienced producers and the novices. This second learning process is coupled with a socialization mechanism aiming at transmitting the milieu's social norms.

Keywords: collective learning; economic sociology; exponential random graph models; organic farming; biodynamic farming; social network analysis; viticulture.

\section{Introduction}

The relational dimension of learning can be observed in part through the study of social networks, especially through the analysis of advice networks. An advice network is a representation of paths that reveal the circulation of appropriate information among individuals of an organized setting (LAZEGA 2001, 2012; WASSERMAN et al., 1994).

I PhD in Sociology. E-mail: jaimemonteslihn@gmail.com 
Lazega $(2001,2003)$ argues that actors in an organized setting do not only obtain information from their peers when they ask for advice, but that they also take part ina broader strategy to modify to their advantage the structure of social relations in which they participate. From this perspective, actors are involved in status competition and the search for reference groups where they can in the long run exchange resources with other actors in a privileged way. For Newig et al. (2010) and Argyris (1982) as well, the actors take into account their relational context in their actions, in what the authors call double loop learning. This is a type of learning that implies not just a transfer of information, but a reflection of the interrelations among actors and the goals of the action themselves. This paper explores, through empirical study, the link between individuals in a learning process leading to the adoption of green practices and their relational context, more specifically the effect of individuals' values in the selection mechanism (ROBINS et al., 2001). Values are observed based on the ecological choices of wine producers in the long run. The selection mechanism points out from who wine producers obtain advice when they face challenging situations regarding their work.

Previous research has shown that collective learning is a key issue in the agro-environmental transition. Farmers are not isolated and rely on other farmers to obtain appropriate information, allowing them to solve problematic situations related to green practices (LAMINE et al., 2009). This information is used by farmers to make technical decisions. Indeed, Darré (1994) and Compagnone (2004) argue that taking into account the position of farmers in social networks helps us to understand farmers' work and how their agronomic practices are socially contextualized.

The study of advice networks is particularly appropriate when tacit and situated knowledge produced by the community of practice is a key resource in the learning process of new techniques (NONAKA et al., 2009; WENGER 1998; CHIFFOLEAU, 2005). Defrancesco et al. (2008) show that this is especially the case for those who adopt green practices: Adopters are more open to exchanging information with other farmers. In addition, Defrancesco observes that not only does technical information circulate in organized settings, social norms and the opinion of neighboring farmers also are relevant for adopters of green practices. Regarding recent research analyzing advice networks among wine-producers in ecological transition, results confirm 
that learning is a socially situated experience (COMPAGNONE, 2014; CHIFFOLEAU, 2004). Wine producers rely intensively on their peers in order to get information and face problematic technical situations.

Once wine producers have taken the first steps to adopt green practices, they must maintain the ratchet effect of this transition facing specifics technical risks (LAMINE et al., 2009). Nevertheless, previous research has put little attention on social selection mechanisms (ROBINS et al., 2001) among individuals in an inter-organizational setting: whom wine producers that have adopted green practices rely on and ask for advice when they face a problematic technical situation, and if shared values may help to stabilize the access to information.

The main purpose of this paper is to evaluate if wine producers' values have an effect on the selection of their colleagues from whom they get advice in order to get appropriate information when they face problematic technical decisions (NAHAPIET et al., 1998; LAZEGA et al., 2012). The analysis takes into account not only the characteristics of wine producers and their organizations, but also a broader relational context including triadic substructures like transitivity (MONGE et al., 2003) and the presence of preexisting relations that may have an influence on the creation od advice ties (LAZEGA, 1999). This study is about the professional milieuof organic and biodynamic wine producersin the high-end terroir of Côte de Beaune in Burgundy Region, France.

This professional milieu is composed of over 60 heterogeneous wine producers: the pioneers, who actively promoted organic and biodynamic farming at a time when it was still marginal and often misunderstood, mingle with other wine producers more recently committed to organic farming, especially since 2000 in a context of: an increase in aid from the French State to transition to organic farming, a well-established market, and a social and institutional legitimacy of organic methods (SCHIRMER, 2004; RUAULT, 2006). Organic and biodynamic farming represent ecological alternatives to conventional farming which share as a founding principle the prohibition on use of synthetic chemicals (EU, 2007; DEMETER, 2014). This restriction represents a technical challenge for farmers in general, and especially for wine producers: In France, viticulture is one of the agricultural activities with the most intensive use of synthetic chemical products. The wine industry 
accounts for only 3\% of the French agricultural area, but it represents over $14 \%$ of the French annual consumption in phytosanitary products (INRA, 2013 , in value). These synthetic products are used by conventional wine producers to prevent and control vineyard diseases. To protect vineyards from diseases without using pesticides, wine producers following the principles of organic or biodynamic farming are only allowed to use preventive treatments based mainly on copper. The adoption of organic or biodynamic farming hence requires the introduction of a new set of agronomic practices and at the same time implies leaving behind undesirable techniques related to the use of synthetic chemical pesticides (GOULET et al., 2012).

This paper begins with the theoretical background that guided the research hypothesis. It takes as a standpoint an organizational perspective of inter-organizational learning and empirical research on social network analysis and ecological transition of wine producers, in order to understand how values may interact with collective learning. Secondly, methodology includes the description of the statistical model, data and the main variables used in the analysis. A complete network approach and Exponential Random Graph models were used to statistically test the research hypotheses. Finally, results are presented and discussed. One of the main conclusions of this paper is that values have an effect on the collective learning process in an agro-ecological transition context: social selection in the advice network is in part driven by the fact that wine producers are more likely to seek advice from other wine producers whom they share similar ecological values with.

\section{Theoretical Background}

Few studies have been devoted to a systematic observation of advice networks among wine producers. Giuliani and Bell (2004) and Giuliani (2003) studied technological learning among 28 conventional vineyards in Chile. They conclude that knowledge diffusion is not equally distributed among organizations nor explained exclusively by geographic proximity. Indeed, knowledge flows are concentrated within vineyards with advanced absorvative capacities (COHEN et al., 1990). The absorvative capacity refers to a collective cumulative capacity to connect prior knowledge to new information. In this study, advice networks were used to capture the knowledge flows among wine producers. 
Regarding wine producers adopting environmental friendly techniques, Compagnone $(2004,2014)$ studied two sets of 15 and 11 wine producers in two villages in the Burgundy Region to assess how social networks affect the adoption of green practices. According to Compagnone, their relational context and their socio-economic status play an important role in the adoption of green practices. The adoption of practices follows a relational path and a coreperiphery configuration. Regarding socio-economic status, wine producers with the lower socio-economic status present a handicap in the adoption of ecological practices. Compagnone concludes that each of the networks' core members share a common social identity. Chiffoleau (2004) analyses two types of networks among 25 members of a cooperative implementing environmental friendly viticulture in the South of France: the first one refers to daily dialogue and service exchange and the second to advice exchange. Results shows that the two networks are not nested: the daily dialogue and services exchange network is linked to social identities and advice networks is used to solve specific problematic questions. The author concludes that socialization, observed by the first type of network, is more related to lineage or neighborly relations than to professional relations. Chiffoleau concludes that actors prefer to seek advice from more distant colleagues to avoid giving the recognition due to the adviser to a closer colleague (BLAU, 1962).

From those empirical studies, it is possible to learn that social network analysis helps us better understand the learning process among wine producers, but the results are not conclusive. While Compagnone argues that individuals involved in intensive advice exchanges - the core of the network - share a common social identity, Chiffoleau states that actors prefer to separate the spheres of socialization and problem solving and seek advice from colleagues that are not socially close. However, little attention has been paid to the drivers of this social selection process (ROBINS et al., 2001) that would allow analyzing the specific attributes that may favor or limit advice exchange among wine producers. Actors' shared values have not been taken into account even though literature shows that it is an important factor both in ecological transition (DEFRANCESCO et al., 2008; LAMINE et al., 2009) and in advice seeking (NAHAPIET et al., 1998).

Another dimension that has not been systematically included in previous research is the broader structural context in which the actors are involved. 
Social network literature (BARABÁSI et al., 1999; DAVIS, 1970; DE SOLLA PRICE, 1976; LUSHER et al., 2012; SIMMEL, 1950) states that not only are the actors' attributes important in understanding the selection process, there are also structural characteristics of the relationships among actors like reciprocity (GOULDNER, 1960; MAUSS, 1923) (i.e. I look for advice from those who have asked me for advice) or transitivity (i.e.the advisor of my advisor becomes my advisor) that play an important role. Recent research has found that when adding triadic sub-structures to the model of analysis (i.e. transitivity), significant effects related to individuals attributes may become not significant (HARRIGAN et al., 2012; LUSHER et al., 2012; LAZEGA et al., 2012). It implies that the relational context, and not exclusively individuals' attributes, may better explain the creation of social ties. Consequently, in order to test if an individual attribute has a significant effect in social selection, a broader relational context should be taken into account.

From a more theoretical point of view, this paper stands on the general theoretical perspective of economic sociology, namely the work of Emmanuel Lazega $(2002,2009)$ that focuses on the study of social mechanisms, such as collective learning among producers in the same industry. From this theoretical approach, producers are not only competitors, but they also collaborate and depend on each other tosh are important information and learn collectively (NALEBUFF et al., 1996). However, access to other colleagues and the advice they give are not equal for everyone. Actors take into account their relational context in a strategic way (CROZIER et al., 1977; LAZEGA, 1992) in order to reach their advisors and have a reflective attitude towards the interrelations among actors (NEWIG et al., 2010). According to Lazega (2003), the relational context is taken into account by the actor in two dimensions a) the vertical dimension refers to status gaps among actors; and b) the horizontal dimension denotes actors' search for reference groups.

The vertical dimension of actors' relational context accounts for the consideration of status gaps between the actor and their potential advisors. Asking for advice implicitly requires social recognition to the advisor (BLAU, 1962; LAZEGA, 2001). From this perspective, actors will avoid asking for advice from colleagues with a lower status. The specific way in which status has been taken into account for wine producers in agro-ecological transition will be explained further in the methodological chapter. 
The horizontal dimension of actors' relational context takes into consideration the belonging of actors in reference groups. According to Lazega (2002, 2003, 2009), producers seek to exchange advice with peers whom they can trust and collaborate with in the long run, putting the competitive or purely strategic rationality aside among a limited number of peers who are members of these specific social groups. Sharing the same attribute or opinion can foster a privileged advice exchange. Homophily (CENTOLA et al., 2007; FELD, 1982; MCPHERSON et al., 2001) is the tendency to select an advice partner based on a common social characteristic such as gender, common values (BREIGER, 2004; NAHAPIET et al., 1998; LAZEGA, 2001; LAZEGA et al., 2012) or geographical location (GULATI, 1999; PARGUEL et al., 2007; VIRY, 2012). This paper focuses on the analysis of the horizontal dimension even if the vertical one is also taken into account as a control variable.

Based on social capital theory, Nahapiet and Ghoshal (1998) argue that advice seeking is driven by three dimensions: a structural part based on formal organization of work; a relational part based on trust: actors seek advice from those they can trust or are friends with; and a cognitive part: actors tend to seek advice from those who have similar values. The third dimension will be tested in this paper and refers to shared representations, interpretations and systems of meanings. Ecological values can help wine producers identify each other and hence facilitate the selection of an advisor among many potential ones. This common cognitive dimension associated to specific values may be relevant to enhance the exchange of knowledge in reference groups where actors aim to collaborate in the long run and need to found their exchanges in other criteria than the purely strategic rationality.

Also based on social capital theory, Burt (2007) states that individuals of a group have a high performance if the group combines cohesion (in-group density of ties), and structural holes outside the group: when individuals have many non-redundant contacts beyond their group. This integration of network closure and structural holes may have an effect on the adoption of organic and biodynamic techniques. This paper explores to what extent common values among wine-producers drive the creation of cohesive groups, and help those who share green values to effectively spread not only the technical knowledge but also social norms beyond their group of reference. 


\section{Hypotheses}

Based on these theoretical foundations, we elaborate three hypotheses regarding social selection mechanisms in seeking advice:

H1. Wine producers are more likely to seek advice from other wine producers with whom they share the same values

This hypothesis aims to take into account the horizontal dimension of the actors' relational context. Under this assumption, a wine producer will preferentially ask for advice from another wine producer with whom he/she shares values (NAHAPIET et al., 1998; BREIGER, 2004). This homophily dimension refers in this research to the ecological choices of wine producers over a long period of time. A distinction has been made between wine producers who have never used synthetic chemical products or have stopped their use before the increase of State subsidies to organic farming in 2000, and those who have more recently left conventional practices behind (GOULET et al., 2012). The hypothesis assesses whether wine producers who have never used pesticides or stopped using them before 2000 tend to look for advice from peers that share the same attribute (in comparison with wine producers that stopped the use of synthetic chemical products afterwards).

\section{H2. Advice exchange tends to be organized in transitivity sub-structures}

The second hypothesis is based on the classical structural sociological theories, which highlight the collective and triadic (i.e. not only dyadic) substructures of social interactions (SIMMEL, 1908; LÉVI-STRAUSS, 1967). Dyadic sub-structures like reciprocity refer to the link between two actors: A asks for advice from B and B asks for advice from A. On the other hand, triadic sub-structures denote the interaction of at least three individuals. If A ask for advice from B, and B from C, A will tend to ask for ask for advice from $C$. The notion of at least three individuals is mentioned because if $A$ asks also for advice from $\mathrm{Z}$ and $\mathrm{Z}$ from $\mathrm{C}$, this additional path will reinforce the tendency of transitivity closure between A and C (DAVIS, 1970). Recent social network research has stated that this collective dimension of exchange should be taken into account since empirical data has shown that this is a tendency in social interactions (NEWMAN et al., 2003). Hypothesis H2 explores transitivity and tests the classical ideasabout exchange group dynamics (the advisor of my advisors tends to become my advisor). 


\section{H3. A pre-existing relationship drives the creation of advice ties}

The objective of the third hypothesis is to analyze how seeking advice can be influenced by ties existing prior to starting the organic or biodynamic farming certification process.

Advisor selection mechanisms can be explained by the existence of other types of inter-individual links. Advice may hence be part of a larger exchange system, including multiple and pre-existing links (LAZEGA, 1999; NADEL, 1952; WHITE, 2008) or, on the contrary, have an independent path from resource exchange, as shown by Chiffoleau (2004). This hypothesis examines specifically the co-occurrence of two types of ties: technical advice and mentorship ties. Mentorship ties refer to the link with other wine producers before beginning the certification process that has had an influence on their decision.

In order to test this series of hypotheses, the analysis takes into account control variables that have been used in previews studies: social, political and economic forms of status (COMPAGNONE, 2014; LAZEGA, 2003; WEBER, 1922) that capture the vertical dimension of actors' relational context; the positioning of wine producers in the export market (WHITE, 2002); and geographical proximity (GIULIANI et al., 2004; CHIFFOLEAU, 2004).

\section{Methodology}

The French Burgundy region i san interesting setting to study the collective learning mechanisms underlying the adoption of green practices for various reasons. From 2000, two important situations have modified the rapport of wine producers to organic farming. The first is the large increase of French aid to organic farming, and the second is a water crisis that occurred in 2002 in Côte de Beaune where local authorities banned the consumption of current water at a time of peak of tourist affluence in the area. The local population pointed to the pesticides of conventional wine producers as the cause of the water crisis. Indeed, the number of certified vineyards in organic and biodynamic farming increased dramatically over the past decade in Côte de Beaune. From 2 farms in the late 1980s, there were 55 organic vineyards in 2011 and their number doubled from 2006-2011. Another element characteristic of this socioprofessional milieu is that, at the time of the research, there was no record of wine producers switching back from organic to conventional farming. 
This number of vineyards is big enough to justify an analysis of the advice network that can capture complex regularities in collective learning mechanisms that cannot be assessed exclusively by an ethnographic work. Wine producers working in these vineyards are competitors in the same industry that, due to their geographical proximityand common characteristics of micro-climes in Côte de Beaune, may collaborate through specific social mechanisms such as collective learning (LAZEGA, 2002, 2009). Another common characteristic shared by these wine producers is their high-end position in the market: almost all of their production is sold directly in bottles. The adoption of organic practices is seen by wine producers as a risky decision with strong economic and symbolic (prestige-related) consequences in case of failure. In that sense, the information that they may share to make appropriate technical decisions is vital in order to face those risks. At the same time, they are not homogeneous. In this social milieu, pioneers of organic farming coexist with a large number of wine producers that have adopted green practices more recently, small vineyards with just a few employees and large vineyards, different market positions, biodynamic and organic certification, etc. This heterogeneity within this social setting allows us to explore the factors that favor or limit the creation of advice ties. A complete network approach was indeed appropriate for this population (LAUMANN et al., 1989; LAZEGA, 1998) in order to explore the structural features of advice exchange. A complete network approach takes into account all the members of a social setting and the presence or absence of relationships among them regarding advice seeking. Complete approach differs from ego-network approach because in the latter, social relations among cited individuals by the actor are not known. The specificity of complete networks is the possibility to take into consideration indirect social relations and to explore their effect on social mechanisms such as collective learning.

The data on which the analysis is based relies on a 3-month ethnographic work and 62 face-to-face questionnaires to organic wine producers in the French terroir of Côte de Beaune, Burgundy in 2012. The first part of our fieldwork consisted of over 20 semi-structured interviews and 2 participant observations with wine producers. The objective was to dig into their daily work and productive tasks, but also to understand to what extent winemakers rely on each other to solve problematic technical situations. 
At this stage of our research, we defined a boundary relevant for the development of a complete network approach selecting the socio-professional milieu based on theoretically and ethnographically based criteria (LAZEGA, 1998): the producers had to exchange knowledge and other resources, to conduct the same types of tasks and to face similar risks related to technical decisions. The common denominator of their technical constraints was the respect of the specifications of organic farming. It was indeed a common characteristic of all the wine producers: those who were not yet certified but have started the official certification, organic and biodynamic farmers have to respect these specifications that give a common framework of allowed and banned technical practices.

As a result of this ethnographic work, we defined the analyzed population as follows: a) the terroir of Côte de Beaune as territorial boundary (an area of approximat el y 20 x 7 kilometers). Côte de Beaune was chosen because wine producers and key informers perceived the Côte de Beaune as a pertinent socio-professional milieu, and because of the concentration of organic wine producers in this area; b) identification of all the vineyards as either certified organic / biodynamic or engaged in a formal certification process in Côte de Beaune. This element allows us to identify wine producers who face similar constraints when they make technical decisions; c) Identification of wine producers directly involved in key technical decisions related to previously selected vineyards. In that sense, the information they share in the advice network is seen as important to make decisions to face problematic technical situations. Based on this criterion, vineyards' owners and the chefs de culture of each vineyardwere included in the analysis. Based on these three criteria a) b) and c), a total of 52 organic and biodynamic vineyards were identified in 2012 in Côte de Beaune and 69 individuals constituted the members of the milieu. The list of vineyards and wine producers were elaborated and checked with key informers and wine producers who were interviewed during this first step of ethnographic work. From 69 individuals identified as part of this socio-professional milieu, $19 \%$ are women, a slightly lower percentage than the French national rate (23\%). Among the vineyards in organic farming, 9 were also certified in biodynamic farming. Viticulture had the fastest growth dynamic in the Region during 2009-2010 (SEDARB, 2011). Organic farming still represents a marginal way of production at the regional level: The rate of organic farmers in the Region is $2.3 \%$ slightly lower with respect tothe national average (3\%) (SEDARB, 2001). 
The second step was elaborating a questionnaire to interview these 69 individuals face to face. We interviewed 62 (close to $90 \%$ response rate), accounting for $96 \%$ of the 52 vineyards identified. $68 \%$ of interviewees were vineyard owners and the remaining $32 \%$ were "chefs de culture". A high response rate is a sine qua non condition of a complete network analysis, which allows us in turn to include structural properties in the study of collective learning mechanisms. The interview guide comprised questions about the sociological characteristics and the professional background of the individuals, along with specific questions on the vineyard, including a section focusing on technical decisions with open questions and no predefined answers. Based on the list of all identified winemakers within the selected milieu, the interview guide also included a number of questions related to the interdependencies between colleagues, such as, in the case of advice exchange: from which wine producers present in this list have you already asked for advice to help you solve a specific issue related to the soil, the plant or the process of wine making? The answers to this specific question allowed us to build the advice network. Each wine producer cited other colleagues within a pre-defined list of the 69 organic wine producers of Côte de Beaune.

In order to include both individual attributes and triadic sub-structures of the network in the analysis, Exponential Random Graph Models (ERGM) were used (LUSHER et al., 2012; ROBINS et al., 2007; LUBELL et al., 2014). The analysis was carried out using PNet (WANG et al., 2009). ERGM aims to provide insights on how and why a link is created between individuals, by taking into account their relational contexts and individual characteristics. The objective is to understand general and structural trends in the network, which are in turn associated with social mechanisms underlying collective action.

The variables included in the analysis directly related to the hypothesis are:

A dichotomic variable is used to identify wine producers who have not used chemical synthetic products or have never used it. Based on the evolution of the certification rate and that of the organic farming institutional environment in France, 2000 was selected as a representative pivot year to differentiate the actors who developed a long term strategy based on ecological practices that go beyond the certification process. This variable allows us to explore the past of the members of the analyzed socio-professional milieu regarding the consistency of technical green choices over time. The wine producers who stopped using synthetic chemical productsbefore 2000 or that never used them account for 
$41 \%$ or the analyzed milieu. We used this attribute in the ERGM analysis across all the actors of the network to assess whether this normative choice influences the selection of advice partners (H1).

Transitivity (transitive path closure) sub-structure captures the triadic effect that may be present in advice network $(\mathrm{H} 2)$. A positive effect implies that transitive sub-structures paths tend to occur in the advice network. This effect is controlled by other structural effects that are included in the model specification such as arc, reciprocity, popularity, activity and multiple two-paths. In order to capture triadic sub-structures, regularities in the network, such as transitivity and endogenous parameters need to be taken into account. These parameters reflect the sub-structures of the local level in the network having an effect on the creation of ties. They are endogenous because they refer to regularities emerging from mechanisms related to the ties in the network and not to the attributes of individuals. These parameters are for example the arc, which reflects the propensity in the network of the occurrence of directed ties. Another example is activity, which refers to the propensity of asking advice to many individuals; popularity, meaning the tendency of one individual's of being searched for advice by many; reciprocity: actors' likeliness to ask the ones they have been advising for their own advice in return; multiple 2 paths, that indicates the connectivity between pairs of actors at the end of the paths and can be interpreted as brokerage (BURT, 2009); or transitivity, referring to the case when "the advisor of my advisor becomes my advisor". One characteristic of these sub-structures is that some of them are included in others. The simplest unit, that is to say the direct tie (reflected by the parameter arc), is included in reciprocity, popularity, activity and transitivity. In more complex configurations, as in a network characterized by actors that are very active (they often ask for advice to many different actors), there will be a high probability of finding sub-structures containing triads like for example transitivity, if sub-structures such as arc, activity, popularity or 2-paths are not taken into account as control variables in the model. In this case, where the model does not take into account the other endogenous parameters, the tendency towards triad configurations will be observed only because of the high density of the network that is derived from the high activity of the actors and not because of a specific social mechanism that tends towards transitivity. This is the reason that justifies the inclusion of endogenous parameters as control variables that may give alternative explanations to the formations of triads, like arc, popularity, activity and multiple 2-paths. These parameters are illustrated in Table 1. 
A dyadic covariate is included to capture the effect of previous ties in the advice network. This influence network emerges from the question of who contributed to their decision to start a certification process $(\mathrm{H} 3)$.

A set of control variables were included in the analysis based on the cited literature:

Status (LAZEGA, 2003, WEBER, 1922): social(being a pioneer in the certification process), political (having a political or union responsibility), and economic (related to the size of the vineyard) (COMPAGNONE, 2014).

Other technical choices that may be related to individuals' values: Adoption of biodynamic techniques in vineyards, sharing the same village to control for geographic proximity (dyadic covariate), and sharing the portfolio of aggregate clients. This dyadic covariate variable is used to capture the effect of similar international strategies of vineyards. Education, as a proxy for human capital (GUILIANI et al., 2004), was included in the exploratory phase of the model specification but not retained in the model presented here. This variable is non-significant and did not add goodness of fit to the model.

\section{Results}

\section{Descriptive statistics}

Starting with demographic characteristics, wine producers of the analyzed organic socio-professional milieu in Côte de Beaune are on average 48 years old $(\min =27, \max =80, \operatorname{stdv}=11)$ and have been working in their current vineyard for over 17 years $(\min =2, \max =46, s t d v=11) .89 \%$ of production is sold directly in bottles, reflecting its high-end position in national and export markets (mainly Japan, the UK and the US). Vineyards in Côte de Beaune enjoy indeed an excellent reputation. $95 \%$ of the 52 analyzed organic vineyards are family businesses. Their average size is 13 hectares (Standard Deviation =11), but it varies from 2 hectares for the smallest vineyard up to 77 hectares for the largest one. In average, the size is higher than the national average of 8 hectares in 2000 (DELFAU et al., 2001).

The descriptive analysis of the advice network among wine producers shows 214 directed ties among the 69 observed wine producers, and a density of $4.6 \%$. Density is a measure that shows the proportion of links actually 
observed in relation to the total number of possible connections in the network (WASSERMAN et al.,1994; FAUST, 2006). Each actor mentioned on average 3 advisors within the analyzed social milieu.

Graph 1 shows an epistemic core where exchanges are dense and a periphery where fewer advice exchanges take place. 11 wine producers are isolated, which means that they do not ask other wine producers for advice and other wine producers do no either ask them for advice.

Graph 1: Oriented Network of advice exchange among 69 organic and biodynamic wine producers in Côte de Beaune, Burgundy Region, France. Each node represents a wine producer and the arrows are directed from the producer that asks for advice to the wine producer that gives advice. White nodes represent wine producers that have never used pesticides or stopped their use before 2000. Grey nodes represent wine producers that have stopped the use of pesticides in 2000 or afterwards.

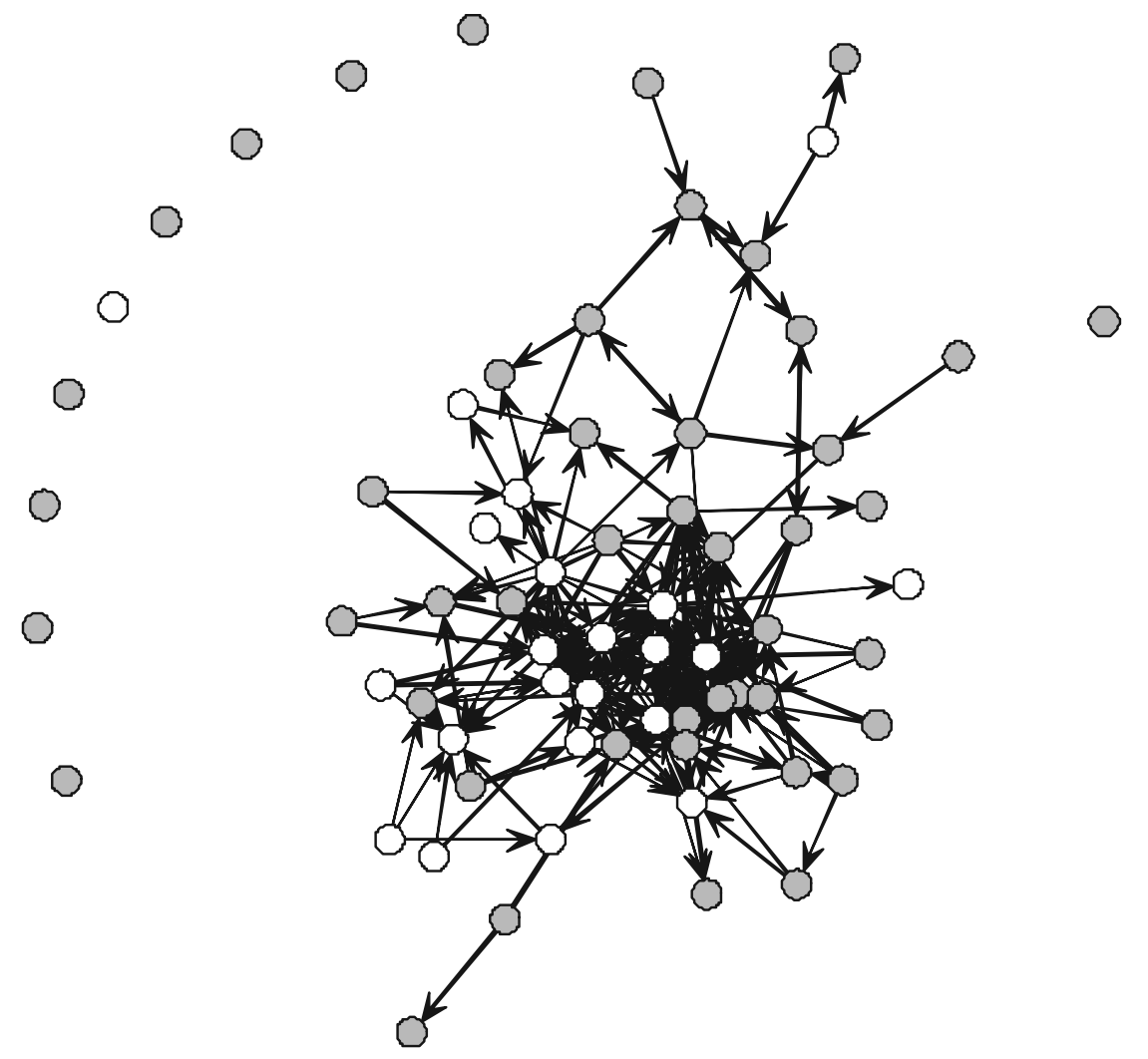


Table I - Parameter estimates for the advice network

\begin{tabular}{|c|c|c|c|c|c|c|}
\hline $\mathbf{N}^{\circ}$ & Parameters & Description & Estimates & SE & t-ratio & \\
\hline & $\begin{array}{l}\text { Purely structural } \\
\text { effects (endogenous) }\end{array}$ & & & & & \\
\hline I & Arc & & -6.09 & 0.47 & 0.03913 & * \\
\hline 2 & Reciprocity & & 0.84 & 0.35 & -0.00035 & * \\
\hline 3 & Popularity [AinS] & & 0.69 & 0.19 & 0.03097 & * \\
\hline 4 & Activity [AoutS] & & 0.80 & 0.18 & 0.03855 & * \\
\hline 5 & Transitivity [AT-T] & & 0.90 & 0.12 & 0.01694 & * \\
\hline \multirow[t]{3}{*}{6} & $\begin{array}{l}\text { Multiple 2-paths }[\mathrm{A} 2 \mathrm{P}-\mathrm{T}] \\
\lambda=6\end{array}$ & & -0.15 & 0.03 & -0.00283 & * \\
\hline & $\begin{array}{l}\text { Actor-relation effects } \\
\text { (exogenous) }\end{array}$ & & & & & \\
\hline & Technicaldecisions & & & & & \\
\hline 7 & Interaction & $\begin{array}{l}\text { Use of biodynamic } \\
\text { techniques }\end{array}$ & 0.05 & 0.40 & -0.00158 & \\
\hline 8 & Interaction & $\begin{array}{l}\text { Nonuse of synthetic } \\
\text { chemicals since } 2000\end{array}$ & 1.00 & 0.31 & 0.03502 & * \\
\hline 9 & Sender & $\begin{array}{l}\text { Use of biodynamic } \\
\text { techniques }\end{array}$ & 0.20 & 0.34 & -0.01463 & \\
\hline 10 & Sender & $\begin{array}{l}\text { Nonuse of synthetic } \\
\text { chemicals since } 2000\end{array}$ & -0.72 & 0.24 & 0.01677 & * \\
\hline 11 & Receiver & $\begin{array}{l}\text { Use of biodynamic } \\
\text { techniques }\end{array}$ & 0.30 & 0.34 & 0.05086 & \\
\hline 12 & Receiver & $\begin{array}{l}\text { Nonuse of synthetic } \\
\text { chemicals since } 2000\end{array}$ & -0.50 & 0.23 & 0.04585 & * \\
\hline
\end{tabular}




\begin{tabular}{|c|c|c|c|c|c|c|}
\hline $\mathbf{N}^{\circ}$ & Parameters & Description & Estimates & SE & t-ratio & \\
\hline & Status & & & & & \\
\hline 13 & Interaction & $\begin{array}{l}\text { Political - Union } \\
\text { representation }\end{array}$ & -0.27 & 0.34 & -0.00458 & \\
\hline 14 & Interaction & $\begin{array}{l}\text { Social - Certification before } \\
2000\end{array}$ & -0.60 & 0.47 & 0.09288 & \\
\hline 15 & Interaction & $\begin{array}{l}\text { Economic - Vineyard of less } \\
\text { than } 7 \text { ha }\end{array}$ & 1.40 & 0.40 & 0.05079 & * \\
\hline 16 & Sender & $\begin{array}{l}\text { Political - Union } \\
\text { representation }\end{array}$ & 0.45 & 0.26 & -0.01762 & \\
\hline 17 & Sender & $\begin{array}{l}\text { Social - Certification before } \\
2000\end{array}$ & 0.64 & 0.23 & 0.03106 & * \\
\hline 18 & Sender & $\begin{array}{l}\text { Economic - Vineyard of less } \\
\text { than } 7 \text { ha }\end{array}$ & -0.01 & 0.15 & 0.08261 & \\
\hline 19 & Receiver & $\begin{array}{l}\text { Political - Union } \\
\text { representation }\end{array}$ & 0.37 & 0.26 & 0.05638 & \\
\hline 20 & Receiver & $\begin{array}{l}\text { Social - Certification before } \\
2000\end{array}$ & 0.45 & 0.24 & 0.07519 & \\
\hline \multirow[t]{2}{*}{21} & Receiver & $\begin{array}{l}\text { Economic - Vineyard of less } \\
\text { than } 7 \text { ha }\end{array}$ & -0.70 & 0.28 & 0.02432 & * \\
\hline & Contextualeffects & & & & & \\
\hline 22 & Dyadiccovariate & Influence network & 2.13 & 0.33 & -0.02371 & * \\
\hline 23 & Dyadiccovariate & Same village & 0.87 & 0.17 & 0.03566 & * \\
\hline 24 & Dyadiccovariate & $\begin{array}{l}\text { Same clients (export } \\
\text { countries) }\end{array}$ & 0.73 & 0.24 & -0.06088 & * \\
\hline
\end{tabular}

Notes: * means significative effect. SE: Standard errors

\section{Model Specification}

To explore the validity of our hypotheses, structural parameters of ERGM were analyzed.

Exponential Random Graph Models (ERGM) are a class of statistical model aiming to analyze and understand the regularities that help explain the creation of social ties in a social network. They model the observed network in terms of small local-based structures like reciprocity or triads, and assume that the patterns observed can be seen as evidence of ongoing social processes. 
ERGM are consistent with the idea that network ties do not only depend on these local-based sub-structures, but are also influenced by actors' attributes and other exogenous factors. Even if social networks have regularities, ERGM include a stochastic element, assuming that the creation of ties is not completely determined by the structure of the social network or by the actors' attributes.

From an operational standpoint, the model assigns,based on a set of local-based structural parameters and the attributes chosen by the researcher and founded on theoretical interest, a probability of a given network. This probability depends on how many of these local-based sub-structures are present, and the parameters give information on the importance of each configuration in creating and sustaining the network. This in turn allows inferences about the social processes that are relevant in the network (LUSHER et al., 2012).

In order to determine the parameters evidenced by data, the test of significance that is used is the Approximate Wald Test. A parameter is significantly different from zero if the parameter estimate divided by the standard error of the estimator is lower than -2 or higher than 2 . The test checks if the estimate is within two standard error units of 0 . The level of 2 is a conservative choice that is robust to distributional assumptions for the sampling distributions of the estimators (LUSHER et al., 2012).

As seen in Table 1, Arc (effect $\left.\mathrm{N}^{\circ} 1\right)$ presents a negative and significant effect. It can be interpreted as a baseline propensity of occurrence of ties.

Reciprocity ( $\left.\mathrm{N}^{\circ} 2\right)$ stands out as a positive and significant parameter, which indicates that wine producers tend to reciprocate advice exchange.

Popularity [AinS] $\left(\mathrm{N}^{\circ} 3\right)$ also appears as a positive and significant parameter, indicating that the popularity, which is reflected by the number of times a wine producer is quoted by his/her colleagues in the advice exchange network, is not equally distributed across the network. Indeed, a small number of winemakers were quoted several times and are hence considered to be popular in the advice network. This parameter captures the skewedness of the in-degree distribution.

Activity [AoutS] ( $\left.\mathrm{N}^{\circ} 4\right)$ presents a positive and significant effect as well: analogous to the popularity parameter, this effect reflects a concentration of 
activity in the network. Certain active farmers tend to have several links or advice requests, i.e. they typically ask multiple colleagues for advice. This parameter captures the skewedness of the out-degree distribution.

It is important to note that wine producers with high popularity (indegree) do not necessary possess a high activity (out-degree). In fact, a specific parameter [AinAoutS] was introduced to test this relationship but did not prove to be a relevant parameter, and thus was removed from the final model.

Multiple 2-path $[A 2 P-T]\left(\mathrm{N}^{\circ} 6\right)$ stands out as a negative and significant parameter, which means that this substructure is not as present as it might be in a random network. This reflects that local connectivity between pairs of actors at the end of the paths is weaker than expected given the other parameters of the model. This can be interpreted as follows: brockerage (BURT, 2009) is a social mechanism that does not tend to occur in this social milieu, and particularly not in the core, the most dense part of the network.

Transitivity parameter $[A T-T]\left(\mathrm{N}^{\circ} 5\right)$ : a positive and significant effect of the Transitivity parameter indicates a strong trend towards transitive closure: the advisor of my advisors tends to become my advisor. This result confirms hypothesis H2: in an advice network, there is a clear tendency towards transitivity in the collective learning process. This result can be interpreted sociologically as a tendency to solve technical problems in group-wise structures. Such structures are strongly driven by transitivity.

A trend towards cooperation, rather than competition, emerges between producers in search for reference groups where wine producers can reach for advice (LAZEGA, 2003). Our ethnography work confirms this tendency: wine producers expressed their preference to be involved in stable informal groups with other producers, where they can share information and experiences.

As for individual attributes, and as per hypothesis H1, we then examined the presence of a tendency towards a normative homophily effect that is driven by common shared values. The interaction parameter $\left(\mathrm{N}^{\circ} 8\right)$ related to this variable is positive and significant. It confirms the presence of propensity towards homophily and validates hypothesis $\mathrm{H} 1$, which states that wine producers tend to seek advice preferentially from peers sharing similar values. Common values are observed in the wine producers' adherence to 
green practices. Those who have never used synthetic chemical products, or who have stopped using them more than a decade ago, tend to seek advice from other wine producers that share similar levels of commitment to green principles. This pattern confirms that wine producers consider the technical decisions of their peers - such as the avoidance of synthetic chemicals over the long term - to be a criterion to reinforce cohesive links between individuals sharing the same values (NAHAPIET et al., 1998). This is confirmed in our ethnography work (MONTES-LIHN, 2014). Statistical results identify the observed homophily effect as a driver of the horizontal dimension of relational context: the formation of reference groups where actors tend to exchange advice in privileged ways (LAZEGA, 2003).

Hypothesis $\mathrm{H} 3$ focuses on the effect of pre-existing ties in the social selection process of advice exchange. The positive and significant effect of ERGM model parameter $\left(\mathrm{N}^{\circ} 22\right)$ proves that prior relationships that have been maintained over time further drive the creation of ties in the advice network. $\mathrm{H} 3$ is hence validated, and confirms the presence of an informal support following the certification process and that is based on multiplexity (LAZEGA et al., 1999), i.e. on a relationship that was created well before the transition to organic farming.

A number of control variables were also used in the model. For example, the adoption of biodynamic techniques $\left(\mathrm{N}^{\circ} 7\right)$ was non-significant. The different forms of status that can be attributed to actors (WEBER, 1922) were taken into consideration, namely social status (having certified the vineyard before 2000, $\mathrm{N}^{\circ} 14$ ), political status (having responsibilities in professional unions, $\mathrm{N}^{\circ} 13$ ), and economic status (measured by the size of the vineyard). Low economic status ( $\left.\mathrm{N}^{\circ} 15\right)$, which is shared by wine producers working in vineyards of 7 hectares or less, is the only significant status-based homophily effect. Wine producers with low economic status demonstrated a tendency to seek advice from others sharing similar status. This finding adds a new dimension to the argument of Compagnone (2014), which finds a direct relationship between the handicap of low socio-economic status' and the adoption of green practices. The homophilic effect of the present model shows that adopters of green practices with low economic status prefer to rely on each other's when addressing problematic situations. 
Geographical proximity (GULATI, 1999; PARGUEL et al., 2007; Viry, 2012), measured by the wine producers working in vineyards within the same village $\left(\mathrm{N}^{\circ} 23\right)$ is positive and significant. This effect demonstrates that local dynamics within a village has a direct impact on the learning process. In other words, wine producers tend to seek advice from other organic wine producers within the same village.

Furthermore, sharing aggregated clients (WHITE, 2002) presents a positive and significant effect $\left(\mathrm{N}^{\circ} 24\right)$ : wine producers that share the same top three export destinations are more likely to seek advice from each other's.

Variables that have not been retained in the final model, because they were non-significant and did not contribute to the model were: level of education, certification in biodynamic,and high and medium economic status.

The set of statistically validated hypotheses suggests that local and social dynamics have a substantial effect on the ecological transition. From these results, it is possible to identify the existence of two simultaneous learning processes. The first is based on homophilic tendency among wine producers sharing ecological values in the long run. The second found upon experienced wine producers, with long-standing reputation in organic farming, mentoring beginner organic farmers, who are about to embark on their first steps towards the ecological transition.

The first learning process is characterized by the joint collaboration of experienced wine producers sharing green values. Ethnography work supports the idea that content of this learning process focuses on cutting edge practices regarding organic and biodynamic farming. The main objective of exchanges in this learning process is to advance collectively beyond today's state-of-theart knowledge. The social boundaries defining the profile of the participants in this specific learning process are determined by shared common values.

The second learning process is characterized by the interaction of novice organic wine producers with others that possess significant more experience in the field of organic farming. This learning process is characterized by a technical dimension. In fact, most advice exchanges would aim to resolve technical difficulties(e.g. at the start of a preventive treatment), especially when novice produces enroll in the certification process. Technical assistance 
from experienced organic wine producers helps to maintain the ratchet effect of the ecological transition. This learning process also contains a socialization mechanism because experienced wine producers tend to initiate novices into the implicit social norms on which the professional milieu is founded. Ethnography work shows that this socialization mechanism (learning and recall of social norms) present in the second learning process is led by the experienced green wine producers. Socialization aims to preserve the collective ways in which knowledge is shared and the values that have guided experienced producers' own ecological transition (MONTES-LIHN, 2014).

Graph 1 illustrates these two parallel learning processes. White nodes represent wine producers with green values. They participate in the first learning process where social boundaries are relevant because, as the statistical model showed, they tend to select advisors sharing the same values. Many of them are also in the core of the network. However, this preference in the selection of advisors does not mean that social boundaries are completely closed. In fact, they tend to vanish when wine producers participate in the second process that includes learning and socialization with others that do not share the same values. In Graph 1, wine producers with green values that stopped using synthetic chemical products before 2000 or never used them (white nodes) also interact with novice organic wine producers that have stopped using them more recently (grey nodes). This configuration reminds the idea described by Burt (2007) that a network combines groups where there is a high cohesion and other ties outside the group that are less dense and allow the members of the cohesive group to have non-redundant contacts beyond the group.

The socialization process that novices embark on starts well before the initiation of the formal certification process. Statistical analysis indicates that the links created prior to the certification process structure the advice exchange network within which the novice engages (hypothesis H3) (LAZEGA et al., 1999). Wine producers tend to validate their strategic decisions by conversing withmore experienced organic wine producers. This validation is more than just technical as it also covers social norms. Moreover, the advice-seeking mechanism represents a form of allegiance to, and status recognition for, experienced organic wine producers (LAZEGA, 2001). 


\section{Discussion and Conclusion}

The adoption of green practices, a process that is institutionalized by the certification procedures, is far more than a mere technical affair. It implies complex social mechanisms, which include collective learning and a socialization process that transcend the technical specifications of organic farming.

Previous research on wine producers facing ecological transition has not systematically taken into account such relational dynamics, especially not the ways in which triadic sub-structures influence the learning process. Another aspect that has received little attention from empirical research is how shared values may have influenced the learning process. However, the results of this empirical study have shown that both variables impact collective learning in the context of ecological transition.

Results have also revealed that there are two simultaneous collective learning processes, both of which are pivoted by the experienced wine producers. In the first learning process, participant wine producers that adhere to ecological values prefer to seek advice from those that share similar values. The content of knowledge sharing among such wine producers revolves around state-of-the-art organic and biodynamic farming practices. In the second learning process, social boundaries are dimmed, allowing novices access to input from experienced organic wine producers. The technical support of experienced wine producers is usually provided before the initiation of the certification process, and stretches far beyond. Such support is provided in the form of knowledge sharing on daily tasks and is even more likely when tackling riskier decisions. The second learning process helps to maintain the ratchet effect of new comers' transition into organic farming. In fact, until 2012 there were no records of wine producers going back from organic to conventional farming in Côte de Beaune. Nevertheless, this leaning process is not exclusively technical; it is coupled with a socialization mechanism that reinforces the social norms of the socio-professional milieu among the new generation of organic wine farmers.

These results explain how farmers learn collectively when facing an ecological transition and also shed the light on theories linking collective learning and social networks to green transition. Moreover, empirical research 
allows us to observe how the characteristics of both single and double-loop learning coexist in this situation (ARGYRIS, 1982; NEWIG et al., 2010). On one hand, wine producers are indeed oriented to solve problematic situations and improve their practices (single-loop learning). On the other, they have a reflective attitude towards the interrelations within which they engage with their peers (doble-loop learning, LAZEGA, 2003; NEWIG et al., 2010). One aspect of this reflective attitude is with respect to shared values (NAHAPIET et al., 1998). For instance, long-found commitment to green values influences the selection of advice partners. Furthermore, actors involved in ecological transition are not only actively sharing their knowledge but are also part of the larger socialization mechanism that starts well before the official certification process towards organic farming. The ecological transition not only implies the adoption of a new set of techniques, but also endorses social norms that allow new players to fully integrate within the community of practice.

\section{Literature cited}

ARGYRIS, C. 1982. Reasoning, learning, and action: Individual and organizational (pp. 85101). San Francisco, CA: Jossey-Bass.

BARABÁSI, A. L.; RÉKA, A. 1999. Emergence of scaling in random networks. Science 286.5439: 509-512.

BLAU, P. M. 1962. Patterns of Choice in Interpersonal Relations. American Sociological Review, 41-55.

BURT, R. S. 2007. Structural Holes versus Network Closure as Social Capital. University of Chicago and Institute Européend'Administrationd'Affaires (INSEAD).

BURT, R. S. 2009. Structural holes: The social structure of competition. Harvard university press.

BREIGER, R. L., 2004. The analysis of social networks. In: Hardy, Melissa, Bryman, Alan (Eds.), Handbook of Data Analysis. Sage Publications, London, pp. 505-526

CENTOlA, D.; GONZALEZ-AVEllA, J. C. Eguiluz, V.M and San Miguel, M. 2007. Homophily, Cultural Drift, and the Co-Evolution of Cultural Groups. Journal of Conflict Resolution 51 (6): 905-29.

CHIFFOLEAU, Y. 2004. Learning about Innovation through Networks: The Development of Environment-Friendly Viticulture. Technovation 25 (10): 1193-1204. 
COHEN, W. M.; LEVINTHAL, D. A. 1990. Absorptive capacity: a new perspective on learning and innovation. Administrative science quarterly, 128-152.

COMPAGNONE, C. 2004. Agriculture raisonnée et dynamique de changement en viticulture bourguignonne: Connaissance et relations sociales. Recherches sociologiques, 35(3), 103-121.

COMPAGNONE, C. 2014. Réseaux de dialogues professionnels et dynamique de changements de pratiques de viticulteurs bourguignons Revue Française de Sociologie. Volume. 55.

CROZIER, M.; FRIEDBERG, E. 1977. L'acteur et Le Système. Points

DAVIS, J. A. 1970 Clustering and hierarchy in interpersonal relations: Testing two graph theoretical models on 742 sociomatrices. American Sociological Review: 843-851.

DARRÉ, J. P. 1994. Pairs et experts dans l'agriculture: dialogues et production de connaissance pour l'action. Erès, Ramonville St-Agne.

DELFAU, G.; CÉSAR, G. 2001. L'avenir de la viticulture française: Entre tradition et défi du Nouveau Monde.

DESOLLA PRICE, D. J. 1976 A general theory of bibliometric and other cumulative advantage process. Journal of the American Society of Information Science 27: 292-306.

DEFRANCESCO, E., GATTO, P.; RUNGE, F; TRESTINI, S. 2008. Factors Affecting Farmers' Participation in Agri-environmental Measures: A Northern Italian Perspective. Journal of agricultural economics, 59(1), 114-131.

DEMETER 2014 Cahier de Charges Productions végétales et animales Edition novembre

EU 2007. Réglement (CE) No 834/2007 DU CONSEIL du 28 juin 2007 relatif à la production biologique et à l'étiquetage des produits biologiques et abrogeant le règlement (CEE) $n^{\circ}$ 2092/91

FAUST, K. 2006. Comparing Social Networks: Size, Density, and Local Structure. Metodološkizvezki, Vol. 3 (2): 185-216.

FELD, S. L. 1982. Social Structural Determinants of Similarity among Associates. American Sociological Review, 797-801.

GIULIANI, E. 2003. Knowledge in the Air and Its Uneven Distribution: A Story of a Chilean Wine Cluster University of Sussex. SPRU. 
GIULIANI, E; BELL, M. 2004. When Micro Shapes the Meso: Learning Networks in a Chilean Wine Cluster. University of Sussex. The Freeman centre.

GOULET, F; VINCK, D. 2012. L'innovation Par Retrait. Contribution À Une Sociologie Du Détachement. Revue Française de Sociologie 53 (2): 195-224.

GOULDNER, A. W., 1960. The norm of reciprocity: a preliminary statement. American Sociological Review 25, 161-178.

GULATI, R. 1999. Network Location and Learning: The Influence of Network Resources and Firm Capabilities on Alliance Formation. Strategic Management Journal 20 (5): 397-420.

INRA 2013. Vers des agricultures à hautes performances. Volume 4: Analyse des voies de progrès en agriculture conventionnelle.

LAMINE, C.; BELLON, S. 2009. Transitions Vers L'agriculture Biologique. Educagri Editions.

LAUMANN, E. O. MARSDEN, P. V. and Prensky, D. 1989. The Boundary Specification Problem in Network Analysis. Research Methods in Social Network Analysis 61: 87.

LAZEGA, E. 1992. The Micropolitics of Knowledge: Communication and Indirect Control in Workgroups. New York: A. de Gruyter.

1998. Réseaux Sociaux et Structures Relationnelles. Collection Que Sais-Je?, n 3399 , Presses Universitaires de France.

- 2001. The Collegial Phenomenon: The Social Mechanisms of Co-Operation among Peers in a Corporate Law Partnership. Oxford UniversityPress.

- 2003. Rationalité, Discipline Sociale et Structure. Revue Française de Sociologie 44 (2): 305-29.

- 2009. Théorie de la coopération entre concurrents: Organisation, marché et analyse de réseaux. Traité de sociologie économique, 533-571.

LAZEGA, E.; MOUNIER, L. 2002. Interdependent Entrepreneurs and the Social Discipline of Their Cooperation: The Research Program of Structural Economic Sociology for a Society of Organizations Conventions and Structures in Economic Organization: M, Cheltenham, Edward Elgar Publishing, 147-99.

LAZEGA, E.; MOUNIER, L. SNIJDERS, T.; TUBARO, P. 2012. Norms, Status and the Dynamics of Advice Networks: A Case Study. Social Networks 34 (3): 323-32.

LAZEGA, E.; PATTISON, P. E. 1999. Multiplexity, Generalized Exchange and Cooperation in Organizations: A Case Study. Social Networks 21 (1): 67-90. 
LÉVI-STRAUSS, C. 1967. Les Structures Élémentaires de La Parenté. Walter de Gruyter.

LUBELL, M., ROBINS, G., \& WANG, P. 2014. Network structure and institutional complexity in an ecology of water management games. Ecology and Society, 19(4), 23.

LUSHER, DEAN, JOHAN KOSKINEN, and GARRY ROBINS. 2012. Exponential Random Graph Models for Social Networks: Theory, Methods, and Applications. Cambridge UniversityPress.

MAUSS, M. 1923. Essai Sur Le Don. Sociologie et Anthropologie, 143-279.

MCPHERSON, MILLER, SMITH-LOVIN, L. and COOK. J. M. 2001 Birds of a feather: Homophily in social networks. Annual review of sociology : 415-444.

MONGE, P. R.; N. S. Contractor. 2003 Theories of communication networks. Oxford University Press.

MONTES-LIHN J., 2014, Apprentissage inter-organisationnel au sein des réseaux interindividuels: le cas de la conversion de viticulteurs a l'agriculture biologique, thèse de doctorat de l'Université Paris- Dauphine, 3 décembre.

NADEL, S. F. 1952 The theory of social structure. Melbourn, Victoria, Australia: Melbourne University Press

NAHAPIET, J.; GHOSHAL S. 1998. Social Capital, Intellectual Capital, and the Organizational Advantage. Academy of Management Review 23 (2): 242-66.

NALEBUFF, B.; BRANDENBURGER, A.; COHEN, L. 1996. La co-opétition: une révolution dans la manière de jouer concurrence et coopération. Village mondial.

NEWIG, J.,GÜNTHER, D., \&PAHL-WOSTL, C. 2010. Synapses in the network: learning in governance networks in the context of environmental management. Ecology and Society, $15(4), 24$.

NEWMAN, M. E.; PARK, J. 2003. Why social networks are different from other types of networks. Physical Review E, 68(3), 036122.

NONAKA, I., \& VON KROGH, G. 2009. Perspective-tacit knowledge and knowledge conversion: Controversy and advancement in organizational knowledge creation theory. Organization science, 20(3), 635-652.

PARGUEL, P.; COMPAGNONE, C. 2007. Un Dispositif D’appui Aux Agriculteurs Pour L'élaboration de Règles de Production d'AOC. Économie Rurale. Agricultures, Alimentations, Territoires, n. 302: 10-22. 
REYNAUD, J-D. 1989. Les Règles Du Jeu. Colin.

ROBINS, G; ELLIOTT, P.; PATTISON, P. 2001. Network Models for Social Selection Processes. Social Networks 23 (1): 1-30.

ROBINS, G.; PATTISON, P.; KALISH, Y.; LUSHER, D. 2007.An Introduction to Exponential Random Graph Models for Social Networks. Social Networks 29 (2): 173-91.

RUAUlT, C. 2006. Le Conseil Aux Agriculteurs`Bio’: Un Analyseur Des Interrogations et Évolutions Du Conseil En Agriculture. Conseiller En Agriculture, Inra, Educagri Éditions, 183-204.

SCHIRMER, R. 2004. La Viticulture Bio, Une Nouvelle Modernité.

SEDARB. 2011. Observatoire Régionale. L'Agriculture Biologique En Bourgogne. Résultats 2010.

SIMMEL, G. 1908. Le Croisement Des Cercles Sociaux. Sociologie: Études Sur.

SIMMEL, G.; WOLFF, K. H. 1950.The sociology of Georg Simmel.Simon and Schuster.

VIRY, G. 2012. Residential Mobility and the Spatial Dispersion of Personal Networks: Effects on Social Support. Social Networks 34 (1): 59-72.

WANG, P.; ROBINS, G.; PATTISON. P; 2009. P Net Program for the Simulation and Estimation of Exponential Random Graph ( $\left.\mathrm{p}^{*}\right)$ Models. http://sna.unimelb.edu.au/_data/ assets/pdf_file/0006/662865/PNetManual.pdf.

WASSERMAN, S. 1994. Social Network Analysis: Methods and Applications. Vol. 8. Cambridge university press.

WEBER, M. 1922 [1978]. Economy and Society: An Outline of Interpretive Sociology. Vol. 1. Univ of California Press.

WENGER, E. 1998. Communities of Practice: Learning, Meaning, and Identity. Cambridge University Press.

WHITE, H. C. 2002. Markets from Networks: Socioeconomic Models of Production. Princeton University Press. . 2008. Identity and control: How social formations emerge. Princeton University Press. 


\section{Aprendizado Coletivo e Socialização num Processo de Transição Ecológica: o caso dos viticultores orgânicos e biodinâmicos da Côte de Beuane}

\section{Resumo}

Os viticultores que enfrentam a transição em direção da agricultura orgânica apoiam-se fortemente em redes informais de conselho entre parceiros. Pouca atenção tem sido dada até agora ao impacto dos valores dos agentes no processo de aprendizado coletivo, ainda que a literatura tenha demonstrado que os valores cumprem um papel importante tanto na transição ecológica (Lamine et al. 2009) como no intercambio de conselhos informais (Nahapiet et al. 1998). O presente artigo examina o efeito dos valores ecológicos dos agentes numa rede completa composta por um mileu profissional de mais de 60 viticultores orgânicos e biodinâmicos da região de Borgonha, na França. Mediante exponential random graph models, são analisados não só os valores dos viticultores, como também seu contexto relacional mais amplo, com a presença de subestruturas de transitividade e a existência de relações pre-existentes que podem influenciar a rede de conselhos. Os resultados mostram que os valores dos viticultores influem na seleção de colegas aos quais se demandam conselhos. Dois processos de aprendizado simultâneos têm sido identificados: o primeiro está caracterizado pela colaboração mutua entre viticultores que tem uma grande experiência e compartilham os mesmos valores ecológicos. O segundo processo está associado com um processo de socialização que conduz à transmissão das normas sociais deste mileu.

Palavras-chave: aprendizado coletivo; sociologia econômica; exponential radom graph models; agricultura orgânica; agricultura biodinâmica; redes sociais; viticultura.

Recebido em 04/03/2016

Aceito em 28/12/2016 